\title{
Spa Tourism - A Comparative Analysis On Spain And Romania
}

\author{
PhD Aluculesei Alina-Cerasela
}

Academy of Economic Studies, Bucharest

\begin{abstract}
Spa tourism is one of the oldest forms of tourism, capitalizing on the curative properties of mineral waters ever since antiquity. At first, the results of such treatments were questioned by health professionals, but the results of numerous studies conducted on the properties of these therapeutic factors have earned them the credibility needed in order to be prescribed by general practitioners as complementary forms of treatment.

Spa tourism is becoming increasingly important in Romania and Spain, especially since both countries are characterized by low birth rates, making health care for the elderly population a priority. The annual spa cure is encouraged with social programs such as "One Week of Recovery" or IMSERSO which facilitate the purchase of health tourism packages for retired citizens.

This research is aimed at highlighting modern health tourism through a comparative analysis of two hotel units specialized in spa treatments, one in Romania and one in Spain. In order to collect the information I used the interview method, the observation method and desk research in the case of information generated from the online environment. The data were collected between January and May 2015.
\end{abstract}

Keywords: spa tourism, spa tourism in Romania, spa tourism in Spain, tourism, thermalism. JEL Classification: L83

\section{Introduction}

Over the course of history, tourism has been a characteristic activity of the most important countries and empires, strengthening their position and level of civilization. Different forms of tourism characterize each period in history - in the Middle Ages, for example, pilgrimage prevailed; then, after the discovery of the New World by explorers like Columbus, Cabot, Da Gama, a new and different wave of tourism appeared, characterized by curiosity or the desire to conquer. Later on, in the nineteenth century, a new concept was developed - The Grand Tour, in which the written accounts of travelers were highly valued among the youth (Gyr, 2010).

The nineteenth century is also characterized by the expansion of this phenomenon among the masses: travel became accessible to the middle class and the working class. At the same time, the descendants of European Americans begin to make trips to Europe in order to know their place of origin. The twentieth century brings new changes. The first half of the century is characterized by mass tourism, and the second half, after the Second World War, is characterized by individual tourism. This change was caused by the development of the automobile industry (with an increasing number of car owners), the emergence of air transportation and the reduction of mandatory working hours (Ryan, 2003).

In the beginning, air transportation was meant only for those with a good financial situation, but, with the advent of large aircraft and with access to significant amounts of fuel, ordinary people were also able to afford airplane tickets even for long distance travel (Thurlow, 2010).

A form of tourism that has retained its importance over the centuries is spa tourism. Its recorded history in Europe starts in Antiquity, when Roman citizens traveled to places with mineral springs for medical purposes. Thanks to this custom, Roman baths were built throughout the conquered territories, some of which have been preserved until today. Their 
significance has influenced other great empires (such as the Moorish Empire) to use baths such as Gerona in Spain for curative purposes, instead of destroying them (Smith, Puzcko, 2014, p. 33).

In terms of main attraction points for tourists interested in recovery cures, Europe has most of the therapeutic resources. One of the countries with a high potential is Hungary, after Japan, Iceland, France and Italy. The spa history of this country is also due to the Roman Empire, who built settlements along the Danube in the first century AD and exploited

\section{Points of view in the literature}

Europe is a continent characterized by countries with an ageing population. Thus, in order to diminish the deficiencies caused by age, a growing number of people turn to spa resorts. Spa tourism helps with workforce recovery and improvement, maintains health status and relieves the symptoms of many diseases, for the elderly but also for children and adolescents (Armand, 1991, p. 29).

The literature defines the term "balneology" as the treatment of diseases by using mineral waters (Medlik, 2003, p. 48). The facilities where these activities occur can be defined in more than one way: the term "spa" means a facility where mineral springs are used for drinking or bathing (Medlik, 2004, p. 154) and it is different from the terms "resort", which is a place with accommodation facilities, the spa resources in the area. Another influence found here is the Turkish influence, which improved and redesigned the Roman baths during the 150 years of Ottoman rule. An important point in the history of the Hungarian spa resorts is the "Peace Treaty of Trianon in 1920, when the country lost more than two thirds of the territory and most resorts of international notoriety, such as Sovata and Tusnad" ( Hall at all, 2006, p. 122). Some of these resorts, (including Sovata and Tusnad) are now on Romanian territory.

especially built for tourists (Collins, 2008, p. 63) and "health resort" - a place with natural factors such as air, mineral water, sunlight and special facilities where people come for treatment, recovery and relaxation (Medlik, 2003, p. 83).

In the beginning, the healing properties of thermal and mineral waters were ignored and questioned by doctors, but today they are widely recognized and enveloped in a new type of medicine: Balneology. "Moreover, in France, since 1947, the French Social Security covers over $65 \%$ of the costs for thermal treatment cures prescribed by doctors" (Conseil National des Exploitans, 2010, p. 29).

Spa tourism is at the border between wellness tourism and medical tourism (fig. 1) and there are many possibilities of treatment cures.

Fig. 1 The position of spa tourism within health tourism

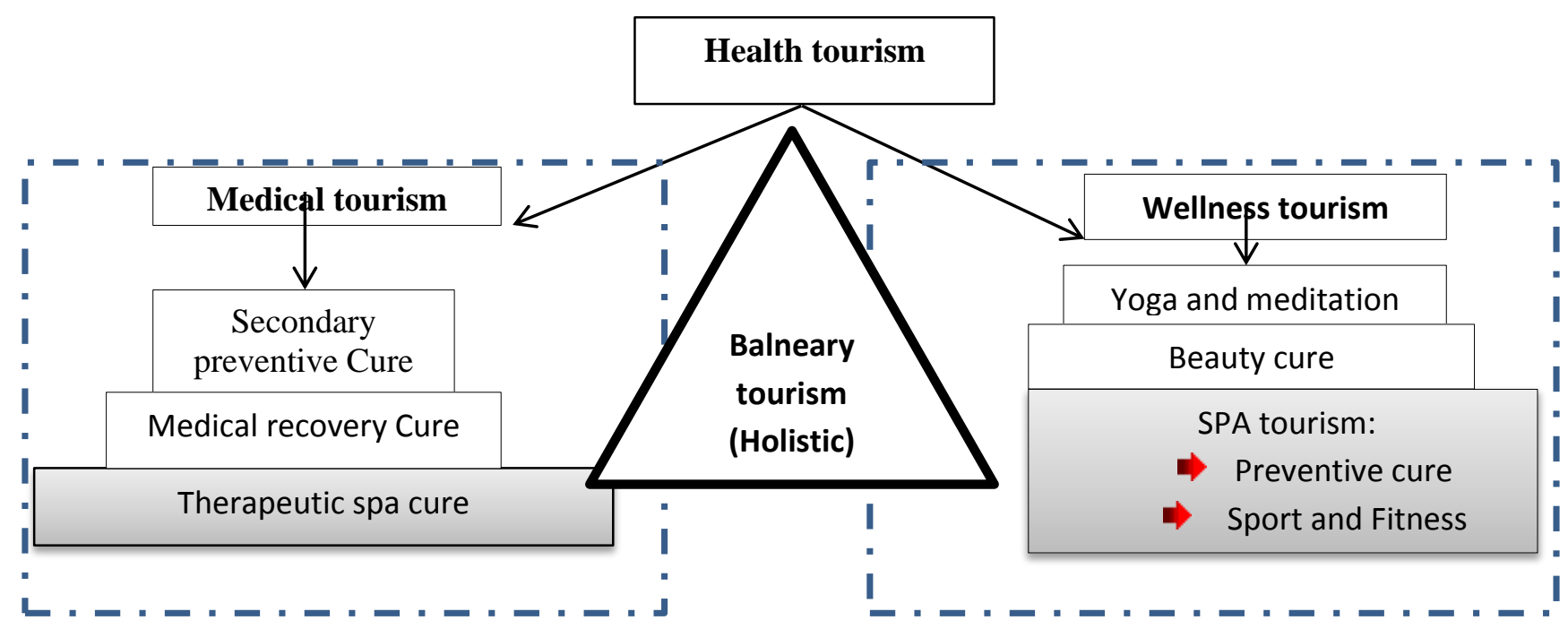


Source: Made by the author, after Stăncioiu, Băltescu, Botoș, Pârgaru (2013, p. 126)

Thus, depending on the resources employed, it can satisfy the needs for wellness, medical benefits or both, covering the needs and desires of a large segment of potential tourists. Depending on preferences or needs, there are many service packages that can be obtained from combining these services, for example, medical recovery courses (specific for medical tourism) can be combined with yoga and meditation sessions or beauty procedures (specific for wellness tourism).

Although natural factors are important, the success of a spa destination does not consist only in its exploitation of certain curative properties. There are many other factors that can help its development and transformation into a destination for medical tourism: location, technology, capital, easy access, security. In order to be attractive for tourists, it must also provide places for recreation, walking paths, social spaces and theaters, in order to complete the experience given by treatment (Weisz, 2011).

The costs of holidays in spa resorts in Western European countries such as France are growing faster than wages and pensions, reaching 1000 to 1200 Euros. In order to still take advantage of the benefits of annual cures, tourists prefer to lower the level of comfort in accommodation, choosing hotels which are rated worse, and without treatment facilities. "At this change in behavior, managers' response did not delay to occur and they offer a new service for customers: free transportation from the accommodation to the treatment centers" (Freire, 2013, p. 35).
In Spain, health cures are highly popular also, both for those who seek cures and for government representatives. The IMSERSO program is an example of such a program and it is under the authority of the National Institute of Social Services (IMSERSO, 2015). It is addressed to elderly citizens, being adapted to their needs in terms of services and prices. The program is benefic for the tourism sector as well, because it solves the problem of seasonality. This cure program was very successful and other countries such as Portugal adopted it also (Moure, 2009).

Prices vary depending on the time of the year (low season / high season) and on whether if transportation is included or not. Prices include: full board, accommodation in a double room, with the possibility of changing it with a single, for a fee of around 13.45 euros / night. Round - trip transportation from the provincial capital to the hotel is provided if the packages include this facility (imserso.es, 2015).

Romania is a country with a vast potential in spa tourism and a rich history in this area. The wide variety of resources put it on the map with high potential destinations (Aluculesei, 2015). Romania is trying to redevelop this segment, visibly damaged in recent decades. Such a measure towards redevelopment is the "One week of recovery" program, initiated by Romanian SPAS Owners Organization (OPTBR). The tariffs differ depending on the type of meal chosen (breakfast / half board) and the comfort level of the accommodation (2 / 3 star hotels). A comparison between tariffs in Spain and Romania is shown in Table 1. 
Table No. 1 Tariff differences between social tourism programs in Spain and Romania

\begin{tabular}{|c|c|c|c|c|}
\hline \multirow{2}{*}{ Destination } & \multicolumn{2}{|c|}{ Tariff 6 nights (euro) } & \multirow{2}{*}{ Destination } & \multirow{2}{*}{$\begin{array}{l}\text { Tariff } 6 \text { nigl } \\
\text { (euro) }\end{array}$} \\
\hline & Low season & Season & & \\
\hline $\begin{array}{l}\text { Andalucía, Catalonia, Murci } \\
\text { and Valencia Community, } \\
\text { with transportation }\end{array}$ & $142,31 €$ & $174,02 €$ & $\begin{array}{l}\text { Romania, Hotel } 2 \\
\text { stars, half board }\end{array}$ & $105,62 €$ \\
\hline $\begin{array}{l}\text { Andalucía, Catalonia, Murci } \\
\text { and Valencia Community, } \\
\text { without transportation }\end{array}$ & $121,52 €$ & $159,32 €$ & $\begin{array}{l}\text { Romania, Hotel } 2 \\
\text { stars, breakfast }\end{array}$ & $74,16 €$ \\
\hline $\begin{array}{l}\text { Baleares Islands, with } \\
\text { transportation }\end{array}$ & $156,64 €$ & $202,76 €$ & $\begin{array}{l}\text { Romania, Hotel } 3 \\
\text { stars, half board }\end{array}$ & $121,35 €$ \\
\hline $\begin{array}{l}\text { Baleares Islands, without } \\
\text { transportation }\end{array}$ & $121,52 €$ & $159,32 €$ & $\begin{array}{l}\text { Romania, Hotel } 3 \\
\text { stars, breakfast }\end{array}$ & $80,90 €$ \\
\hline
\end{tabular}

Source: Made by the author after: http://www.anat.ro and http://www.imserso.es

The two countries have different rates for a stay of 6 nights. The nearest package version is the one with free transportation on mainland Spain - 121.52 euro (during high season) and the Romanian social program that includes 3-star hotel accommodation and breakfast - 121.35 euros. Services included in the IMSERSO social program are: full board and accommodation in a double room, collective medical insurance, medical services and animation activities. The "One week of recovery" program includes 2 or 3 star hotel accommodation with breakfast or half board (depending on customer preferences), the medical procedure program prescribed by the doctor and the medical consultation on arrival.

In terms of average tariffs covered by the government, the Spanish cover 140.42 Euros out of the packages with free transportation and the Romanians cover 95.5 Euros. This difference can be explained through the difference between minimum wages: 750 Euros in Spain and 218 Euros in Romania (Eurostat, 2015).

Thus, the importance of spa tourism is no longer limited to the results of curing certain diseases but it is now much wider - spa tourism is a priority in improving the health status of the elderly population.

\section{Methodology}

This study compares spa tourism characteristics in Romania and Spain by analyzing a representative hotel from each country, with similar characteristics. For this research we travelled to both locations between January and May 2015 and used the interview method in order to collect data. Both the research visits and the interviews were scheduled in advance.

We also used observation and desk research - for information available online. The aspects included in research were: the tariff levels, the esthetic aspect of the resorts, the location of the hotels and treatment facilities.

We used an interview guide, in which 14 topics were followed in regards to the activity in the resort, and an observation form for resorts in which were graded aspects such as overall image of the resort, architecture, promenade areas, access road condition with grades from very weak to very good.

The hotels chosen for the study were Balneari Vichy Catalan from Malavella (Spain), a 3 star hotel, and Danubius Hotel from Sovata (Romania), a 4 star hotel, both with their own treatment facilities in which they exploit the properties of curative waters captured through their own system of pipelines. 


\section{Results}

The Malavella health resort is located near the city of Girona, in the Catalan region of Spain, with two thermal units: Prat Hotel and Hotel Balneari Vichy Catalan. The properties of the thermal waters are suited for the treatment of the following medical conditions and diseases: rheumatism, hepatitis, fractures, digestive disorders, urinary and circulatory disorders (Visitcaldes, 2015, p.3).

The Sovata health resort is located in Transylvania (Romania), "being recognized at the European level since 1850, with lakes with chlorinated and soda water and mud with therapeutic properties" (sovata.ro, 2015). These natural factors are useful for the treatment of gynecological, musculoskeletal, respiratory and dermatological diseases (Pretorian, 2012, p. 49)

\section{Results based on the observation form in the two resorts}

After the research visit in the two spa resorts, an observation form was used in which we monitored issues such as the overall image of the resort, the condition of the building facade, the architecture, the condition of local roads, and the presence of places such as promenades and green spaces. Every detail was given grades encoded on a scale of 1 to 5 , with very poor $=1 /$ poor $=2 /$ average $=3 / \operatorname{good}=$ $4 /$ very good $=5$. The results are described in Table. 2.

Table No. 2 Observation form for Malavella and Sovata health resorts

\begin{tabular}{|l|l|l|}
\hline Issues & Malavella & Sovata \\
\hline Overall image of the health reso & 2 & 4 \\
\hline Buildings & 2 & 3 \\
\hline Architecture & 2 & 3 \\
\hline Local roads & 4 & 3 \\
\hline Access to the health resort & 4 & 4 \\
\hline Places for promenades & 3 & 4 \\
\hline Green spaces & 3 & 4 \\
\hline Average & $\mathbf{2 , 8 6}$ & $\mathbf{3 , 5 7}$ \\
\hline
\end{tabular}

Source: Made by the author according to the research visit from January - May 2015

The Malavella health resort has a poor overall aspect ( 2 points), with old buildings, without neat facades. The architecture of the buildings is not attractive, despite the use of the traditional Spanish style, in shades of yellow and dark red painted terracotta. The Balneari Vichy Catalan hotel is located on the main street and represents the emblem of the resort, impressive in architecture and size and situated right next to the mineral water bottling factory that has the same name. Placing the factory in a location so visible to all tourists creates an unpleasant and somewhat industrial image, with the storage of water bottle pallets near the gateway. The roads are in good condition, and the location is signaled well in advance, on the main road. There are places for promenade and green areas, but only a few and limited in surface (small parks and recreation areas).

The Sovata health resort gained a total of 4 points for the overall image. An important aspect which contributed to this grade was its position in a mountainous area, with beautiful landscape. The architecture in the resort resembles the architecture of the local buildings, but there are several old buildings with unique architecture that are neglected or poorly maintained. The road to the resort and the ones in the resort are in good condition, with the resort being properly signaled on the main road. There are many areas for walking and plenty of green spaces, due to the mountainous 
landscape and there are walking trails around the Bear Lake and other smaller lakes, improving the overall aspect of the Sovata resort.

\section{Results based on the interview at the Balneari Vichy Catalan Hotel}

From the interview with the representative of the Balneari Vichy Catalan hotel, we obtained information about the type of tourists who enjoy spending their time there, the importance of tourists' opinion, facilities, treatments, and methods of promoting the hotel. The interview was set via e-mail and the answer from the hotel manager came in less than 24 hours. For the research visit, the hotel manager offered a guided tour with plenty of explanations about the resort facilities and medical procedures performed in the unit.

In terms of features and services offered by the two hotels we analyzed, the Balneari Vichy Catalan hotel offers treatment for medical conditions such as muscle aches, joint pains, and respiratory and skin diseases. The main services offered are: beauty treatments, personalized treatments, therapeutic treatments (mud, physiotherapy, chiromassage, aromatic massage, foot reflexology), thermal treatments (sauna, alternative shower with mineral water, vertical shower, aerosols) and different types of massage.

In regards to the origin of tourists who choose this unit as their destination, most of them are from Spain, especially from the Catalan region, followed by France, England and Russia, with an average age between 50 and 60 years. An important percentage of the Spanish tourists, 30-40\%, come here through the IMSERSO social program. Factors that determine most of the tourists to choose this unit are, in the opinion of the hotel representative: the brand name reputation in Spain, the location (close to Barcelona and Girona - two strong economical and touristic cities), the proximity to the Mediterranean coast, the quality of the thermal water and last but not least, the presence of an airport at a distance of 10 minutes' drive.

The hotel is not part of a chain; it is a singular hotel, owned by a Spanish
The differences in image between the two resorts are visible through the average scores obtained: 2.86 points for the Spanish resort and 3.57 points for the Romanian resort.

entrepreneur with a strong local footprint, which can be seen in the architecture and the predominant color used in the interior and exterior design. Both the treatment center and hotel were built with personal resources, without European funding.

It is very important for the hotel manager to communicate with tourists and promote the unit using both traditional means (through travel agencies) and the online environment (through websites like Booking.com, through the hotel's own website and through the Malavella resort website). Tourist opinion is highly valued and tourists are encouraged to fill in a satisfaction survey and to provide feedback on TripAdvisor.

The treatment base is very complex, with many cure options for various medical conditions. The base includes two indoor pools with thermal water (at a temperature of $34^{\circ} \mathrm{C}$ ), 13 individual massage cabins, 3 double massage cabins, a dry sauna, a wet sauna, an aerosol inhalation hall, a vertical shower, a contrast shower and Jacuzzi. According to the hotel representative, the most appreciated procedure is the "Thermal circuit", which includes a bath in a Jacuzzi pool, with thermal water at a temperature of $34^{\circ} \mathrm{C}$, chromo therapy, alternative shower, Hamman and Finnish sauna and foot bath.

Thermal water is used in all procedures, and it is collected through a pipe system from a nearby source located a few hundred meters away. Also, in the lobby there is a mineral water fountain from which tourists can drink.

The hotel management crew wants to use local products for treatments (Spanish oil, salt, mud); two such favorite brands are Alchimia and Nature Brasil. Tourists also have the possibility to purchase a variety of products at the reception of the treatment base. Another important aspect is that the employees are from the local community, improving the local image of the unit. 
Results based on the observation visit at the Sovata health resort

Danubius Hotel is part of the Danubius Hotels Group and it is located almost $200 \mathrm{~m}$ away from the main attraction of the resort, The Bear Lake. The treatment base uses water brought through a pipe system from the nearby lake, thus allowing treatments all year round, regardless of the outside temperature. It corresponds to the current rules and regulations; it was modernized in 2004 with funds from the owner.

The base has the following components: 2 indoor swimming pools - one with saltwater and one with freshwater, a tanning salon, a steam bath, Jacuzzi, underwater massage. The treatments done here are: mud wraps, gynecological treatments, treatments for musculoskeletal disorders, and dermatological anti-psoriazis treatments (danubiushotels.ro, 2015).

The hotel is very well promoted, both through travel agencies and the online environment and it has become one of the images associated with the resort. In regards to the products used for treatment, most of them are local products and include salt, mud, oils, and creams. The Romanian Asla Vital brand is promoted here, and its products are exhibited for sale.

Concerning the service fees, they differ from one hotel to another. In the case of Romanian hotels, the packages they offer include treatment and accommodation plus breakfast, and cover a wide range of services, oriented either towards medical services, recovery, or both. In the case of the Malavella hotel, the services provided within the treatment area are advertised separately from the accommodation services which cost about 69 Euros / day for a standard double room. A comparative description is presented in Table No. 3.

Table no. 3 Comparative analyze of treatment tariffs

\begin{tabular}{|l|l|l|l|l|}
\hline Treatment Package & Hotel Danubi & Treatment Package & $\begin{array}{l}\text { Hotel Balne: } \\
\text { Vichy Catalan }\end{array}$ \\
\hline $\begin{array}{l}2 \text { nights of accommodatio } \\
\text { unlimited access at SPA, } \\
\text { sauna }\end{array}$ & $105,39 €$ & $\begin{array}{l}2 \text { nights of } \\
\text { accommodation, therm } \\
\text { circuit of } 60 \text { minutes }\end{array}$ & $150,00 €$ \\
\hline $\begin{array}{l}5 \text { nights of accommodatio } \\
2 \text { recovery massage, } 3 \\
\text { medical procedures }\end{array}$ & $343,82 €$ & $\begin{array}{l}5 \text { nights } \\
\text { accommodation and } \\
\text { thermal circuits of } \\
\text { minutes each }\end{array}$ & $349,00 €$ \\
\hline
\end{tabular}

Source: Made by the author according to the Tariffs Brochure - Printed Version of Balneari Vichy Catalan and http://www.danubiushotels.com/

Both units encourage the purchase of packages consisting of accommodation and medical procedures, which are more cost effective for tourists. Tariffs are similar and in both cases tourists get more benefits purchasing accommodation together with treatment procedures: at the Danubius Hotel, the price for a night of accommodation in a double room is 82 Euros while at the Vichy Catalan Hotel it is 69 Euros.
The tariffs for offers which include 5 nights of accommodation are almost equal in price: 343.82 Euros at Sovata and 349 Euros at Malavella. The true difference is in the structure of the treatment plan: at the Sovata resort hotel, the treatment plan includes both medical and wellness treatment options, while at the Malavella resort hotel the treatment plan includes mainly wellness treatment options. 


\section{The advantages and limitations of the research}

The research presents a comparative image of two representative hotels with treatment bases in resorts located in Spain and Romania, a subject rarely discussed in the Romanian literature.

The main advantage of this study is that it provides a complete picture on the subject by presenting both the hotels and the resorts where they are located. Another advantage is in the methodology - it is based both on research visits and on interviews with hotel representatives, an important and useful aspect in order to paint an accurate picture of the actual situation.

The main limitation of this study is the small number of units included in the survey only two units, one for each country, and therefore the results can't be generalized. Another limitation is that both resorts were observed during the low season, when the tourist flow is reduced.

Thus, this research should be extended to more resorts and hotel units in both countries. This way, we can obtain a complex and comprehensive picture of the actual situation that can be generalized at a national level.

\section{Conclusions}

Both Spain and Romania are countries where health tourism can be traced back to Roman times, when the properties of mineral waters were used for wellness and medical purpose. The results of the research conducted at the Danubius and Balneari Vichy Catalan hotels, lead to the following conclusions:

The social aspect of spa tourism is exploited in both countries through programs for the elderly population, the main consumers of these services (such programs are the IMSERSO program in Spain and the "One week of recovery" program in Romania);

$\Rightarrow$ Tariffs for 6 night accommodation packages differ only by a small amount: in Romania the price is 44.91 Euros smaller on average than in Spain;

$\Rightarrow$ The image of the Sovata health resort is better than the image of the Malavella health resort, scoring 0.71 points more in the analysis based on the observation form;

$\Rightarrow$ The rates for services not included in the social program packages do not differ significantly, if we take into account the fact that the minimum wage levels in the two countries do differ significantly (the Spanish minimum wage is 3.44 times higher);

The Balneari Vichy Catalan Hotel is an IMSERSO program partner, with as many as $30 \%$ to $40 \%$ of tourists coming through this social program. Most tourists are elderly, around 50 to 60 years of age and come mainly from the Catalan region of Spain; the success of the Spanish unit is due to its location, brand name strength and the properties of mineral waters;

The Danubius Hotel has a complex treatment base, modernized in 2004, that provides tourists with a wide range of relaxation and treatment options.

Spa tourism is a key segment for both of the countries included in this study. The authorities are involved in promoting spa tourism through a range of social programs. Even though the minimum wages in Spain are significantly higher than in Romania, tariffs do not differ much, which means that both hotel establishments offer equal quality standards that require similar investments in specific infrastructure.

Thus, Romanian resorts must take advantage of their strengths in order to attract tourists from other countries and increase their notoriety in this domain, strengths such as an exceptional natural environment and the possibility to treat a wide range of diseases and medical conditions.

\section{Acknowledgment}

This work was co-financed from the European Social Fund trough Sectorial Operational Program Human Resources Development 2007-2013 under Grant: POSDRU / 159 / 1.5 / S / 137832 "Cooperation for MINERVA-elite careers in doctoral and postdoctoral research". 


\section{Bibliography}

1. Aluculesei, A.C., Mahika, C.E., Rădulescu, R., Nistoreanu, P. (2015) Organizational Stress for Retail Store Employees in Romania Is Spa Tourism a Solution? The Romanian Economic Journal. 55 (2), pp. 324.

2. Armand, B., Armenier, F., Auge, J. M., Casedevant, B., Darrouzet, J. M., Delaire, P. (1991). Mieux connaître les Cures Thermales chez l'Enfant. Expansion Scientifique Française, Paris, p.29.

3. Bateman, H., Harris, E., Adam, K. (2008) Dictionary of leisure, travel and tourism, $3^{\text {rd }}$ edition. Peter Collin Publishing, London, p.204.

4. Freire, N. (2013) How to Manage French Thermalism Specificities? International Business Research. 6 (3), pp 29-39.

5. Gyr, U. (2010) The History of Tourism: Structures on the Path to Modernity. European History Online (EGO) [online]. Available from: http://www.ieg-ego.eu/gyru-2010-en

6. Hall, D., Smith, M., Marciszweska, B. (2006) Tourism in the New Europe: The Challenges and Opportunities of EU Enlargement. Cabi, Oxfordshire [online]. Available

from:https://books.google.ro/books?id=jv9 hpg79epMC\&pg=PA122\&lpg=PA122\&dq $=$ balneary+tourism+and $+\mathrm{II}+\mathrm{War} \&$ source $=$ bl\&ots=beuBrlbkvc\&sig=ZTx5PewTMqcr OtAqbFGQTl-

QlAk\&hl=ro\&sa $=X \&$ ei $=4 \mathrm{TI}$

VeLKCIKqUen3gNgJ\&ved=0CDoQ6AE $\mathrm{wAw} \# \mathrm{v}=$ onepage $\& \mathrm{q}=$ balneary\%20tourism $\% 20$ and $\% 20 \mathrm{II} \% 20 \mathrm{War} \& \mathrm{f}=$ false

7. Medlik, S. (2003) Dictionary of travel, tourism and hospitality, $3^{\text {rd }}$ edition. Elsevier Science, Kent, p.153.

8. Moure, O.M. (2009) El programa de termalismo social del IMSERSO: la promocion del turismo activo en la tercera edad a traves del aqua. El caso de Galicia. Medicina Naturista, 2 (2), pp 143-147.

9. Pretorian, S. (2012) CALITATEA DESTINAȚIEI - Stațiunea Sovata,
Români. Balneo-Research Journal. 3 (2), pp. 44-62.

10. Ryar, C (2003) Recreational tourism. Demand and impacts. Crpmwell press, Clevedon.

11. Smith, M., Puczko, L. (2014). Health, Tourism and Hospitality: Spas, Wellness and Medical Travel. Routledge, New York, p.33 [online]. Available from: https://books.google.ro/books?id=jv9hpg7 9epMC\&pg=PA122\&lpg=PA122\&dq=bal neary+tourism+and+II+War\&source $=$ bl\&o ts $=$ beuBrlbkvc \&sig $=$ ZTx 5 PewTMqcrOtAq bFGQTl-Q1Ak\&hl=ro\&sa=X\&ei=4TIVeLKCIKqUen3gNgJ\&ved=0CDoQ6AE $\mathrm{wAw} \# \mathrm{v}=$ onepage $\& \mathrm{q}=$ balneary $\% 20$ tourism $\%$ 20and\%20II\%20War\&f=false

12. Stăncioiu, A.F., Băltescu, C.A., Botoș, A., Pârgaru, I. (2013) Aspecte conceptuale privind marketingul turismului balnear din România. Economie teoretică şi aplicată. 2(579), pp. 124-137.

13. Thurlow, C, Jaworki, A. (2010) Tourism discourse. Palgrave Macmillan, London, p.19.

14. Weisz, G. (2011). Historical reflections on medical travel. Anthropology \& Medicine. $1(1)$.

15. http://www.anat.ro

16. http://www.danubiushotels.com/

17. http://ec.europa.eu/eurostat/statisticsexplained/index.php/File:Minimum_wages ,July_2014_(1)_(EUR_per_month)_YB1 5.png

18. http://www.hotelbalnearivichycatalan.cat/c a/centre-termal

19. http://www.imserso.es/imserso_06/envejec imiento_activo/vacaciones/precios_destino s_modalidad/index.htm

20. http://www.sovata.ro

21. http://www.visitcaldes.cat/images/flipbook /whatson/index.html\#/2 